\title{
Dr. Francisco Mauro Salzano, 1928-2018
}

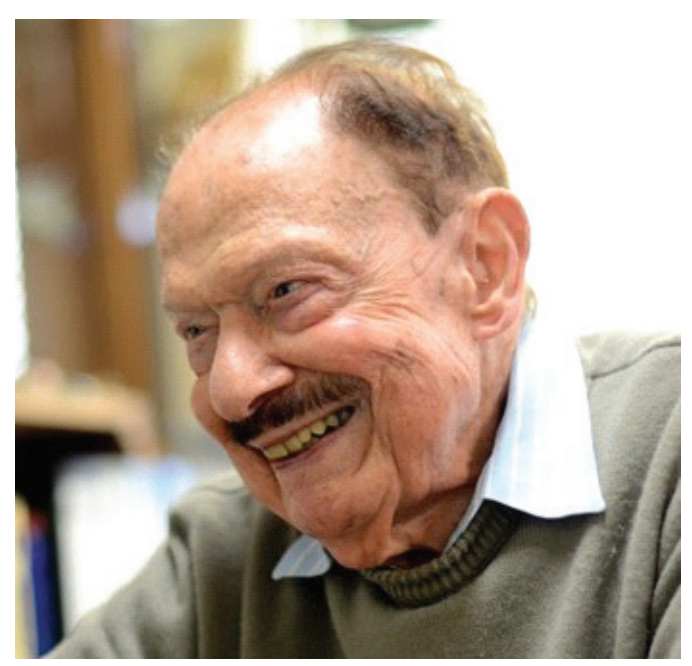

Foto de Gustavo Diehl - UFRGS. http://www.ufrgs.br/ufrgs/ noticias/ufrgs-decreta-luto-oficial-pelo-falecimento-defrancisco-mauro-salzano

El pasado 28 de setiembre, en Porto Alegre (Brasil), falleció Francisco Mauro Salzano, quien fuera fundador, Presidente (1990-1992) y Presidente Honorario de la Asociación Latinoamericana de Antropología Biológica (ALAB) hasta su muerte. Había nacido en Cachoeira do Sul, Rio Grande do Sul el 27 de julio de 1928.

Desde joven, Francisco Salzano se interesó por las ciencias biológicas y, contra la idea de su padre de seguir sus pasos estudiando medicina, ingresó en el bachillerato de historia natural de la Universidad Federal de Rio Grande do Sul (UFRGS). Su interés inicial por la zoología fue rápidamente sustituido por una disciplina de creciente desarrollo: la genética. Fue en la UFRGS donde Antonio Cordeiro, discípulo de Theodosius Dobzhansky, le sugirió esta nueva área de estudio. Rápidamente interesado, Salzano fue a realizar una pasantía en la Universidad Federal de São Paulo, trabajando con Drosophila. Casi por casualidad, según relata en una entrevista realizada por Marcos Pivetta (para la revista Pesquisa, en 2006), logró una beca para realizar allí su doctorado en1955 con Crodowando Pavan, siempre sobre Drosophila como modelo para genética de poblaciones, siendo Dobhzansky miembro de su tribunal.
Un hito importante en la vida de Salzano, y de interés directo para nosotros como antropólogos biólogos, fue su posdoctorado en la Universidad de Michigan (Ann Arbor, 1956), donde conoció a James V. Neel. Juntos comenzaron los estudios en las poblaciones indígenas de Brasil, tema que se refleja en sus primeros artículos, publicados a partir de 1957, y que muestran su interés biológico y antropológico por las poblaciones humanas, en particular nativas, pero también de "negros" brasileños, así como sobre enfermedades genéticas. Sobre estos temas, y muchos otros, publicó hasta este mismo año, en el cual aparecen ya publicados varios artículos.

A lo largo de los años escribió cerca de 1000 artículos y libros, 454 de los cuales componen el índice $\mathrm{H}$ de calidad académica. Pero esa producción no sólo refleja sus investigaciones sino que también sus amplios intereses por la humanidad y los derechos humanos. Preocupado por los problemas sociales, fue convocado en 1964 por UNESCO a la reunión de Moscú, que culminó en la declaración de las "Propuestas sobre los aspectos biológicos de la cuestión racial", siendo uno de los veintidós académicos que las redactaron. En el documento publicado por $E l$ Correo de la UNESCO en 1965 se sostiene que las diferencias entre los seres humanos son debidas a adaptaciones al medio o relacionadas a la historia cultural, sin justificación para los conceptos "razas superiores" y "razas inferiores", y donde se concluye que "Los datos biológicos anteriormente expuestos constituyen una contradicción absoluta de las tesis racistas [...] y constituye un deber para los antropólogos hacer lo posible para impedir que los resultados de sus investigaciones sean deformados por la utilización que podría hacerse de los mismos con fines no cientificos" (UNESCO, 1965:11). Si bien Salzano, hasta el fin de sus días, defendió la aplicación de "raza" a los seres humanos, lo hizo siempre basado en la diversidad biológica y su interés en la variación humana y nunca con un sentido distinto al expresado en la declaración mencionada.

doi:10.17139/raab.2019.0021.01.01 
Mientras que sus artículos muestran su excelente formación académica y su rigor científico en temas como genética de poblaciones humanas (indígenas, afrodescendientes, mestizaje, aspectos teóricos), genética médica, y genética de diversas especies animales y vegetales, sus libros son más versátiles. Estos últimos refieren a diversos temas, como la evolución, buscando llegar a diversos públicos y no solamente al ambiente académico. Entre éstos es posible mencionar "Biología Cultura e Evolucão" (1988), "Voce e sua herença" (1979) o "DNA, e eu como isso" (2005), como también "Pindorama - a Inocência Perdida" (1975), referido a los Tupí-Guaraní de la costa, y “ $A$ genética $e$ a lei: aplicações à medicina legal e à biologia social" (1983). Pero dos libros deben ser señalados como posibles "biblias" para quienes nos dedicamos a la genética de poblaciones humanas y la antropología biológica: "South American Indians: a case study in evolution", escrito con Sidia Callegari-Jacques (1988) e "Interethnic admixture and the evolution of Latin American populations", con Maria Cátira Bortolini (2001).

$\mathrm{Su}$ lugar de trabajo fue en el Departamento de Genética de la UFRGS, que contribuyó a fundar junto con Antonio Cordeiro (inicialmente, Sector de Genética). Allí trabajó hasta pocos días antes de su fallecimiento, en los últimos 20 años como Profesor Emérito. Durante años fue el primero en llegar y último en irse del Departamento, trabajando también sábados y domingos a mediodía. Esta capacidad de trabajo fue ejemplo de quienes lo conocimos, tanto brasileños como de diversas partes del mundo. Allí también dirigió a gran cantidad de tutoreados de posgrado y posdoctorado tanto del Brasil como fuera de éste; en Uruguay, Máximo Drets (19302017) y yo tuvimos ese privilegio, en una época en la que los borradores iban por correo y volvían con las numerosas anotaciones a lápiz de puño y letra de Salzano. En Brasil, varios especialistas en genética humana y poblacional relacionados a la ALAB fueron también orientados por Salzano, como Nelson Fagundes, Sandro Bonatto y Lavinia Schuler-Faccini. Eximio bai- larín, gran disertante y siempre atento cuando correspondía escuchar, participó en diez primeros congresos de la $\mathrm{ALAB}$, hasta el X Congreso de la Asociación realizado en la ciudad de La Plata. En varias oportunidades visitó Uruguay y Argentina, en el marco de eventos y cursos sobre diversos temas de genética de poblaciones humanas y antropología biológica. Dentro y fuera de su ámbito laboral, su calidez, su entusiasmo, su solidaridad, su interés por una diversidad de temas sociales y culturales fueron constantes.

Recibió, a lo largo de su vida una gran cantidad de distinciones y honores como Miembro de la Academia Brasileña de Ciencias desde 1973 y Miembro extranjero de la Academia Nacional de Ciencias de los Estados Unidos desde 1999; Secretario General de la Association of Human Biologists entre 1974-1980; Vicepresidente de la Internacional Union of Anthropologial and Ethnological Sciences entre 1978 y 1983, y miembro de otras muchas asociaciones. También, se le otorgaron numerosas distinciones como el Prêmio Almirante Álvaro Alberto para Ciência e Tecnologia (Brasil, 1994), la Grãn Cruz da Ordem Nacional do Mérito Científico - Presidente da República do Brasil (1995), el Annual Award de la Ibero-American Society of Human Genetics (1995) y el premio Franz Boas - High Achievement Award otorgado por la Human Biology Association (1997). Fue también designado Doctor Honoris Causa de la Universidade Paul Sabatier (Francia) en 2010 y de la Universidad de Costa Rica en 2011.

Quienes tuvimos el honor y la alegría de conocerlo lo recordaremos siempre con su gran sonrisa y sus camisetas coloridas que distraían de su enorme capacidad de trabajo, la rigurosidad científica y la ética en la cual se apoyaban todas sus actividades. Pero, muy especialmente, lo recordaremos por su gran calidez humana. Se fue Francisco Mauro Salzano, su obra perdurará en nosotros.

Mónica Sans Departamento de Antropología Biológica, Universidad de la República, Uruguay 